\title{
The Effectiveness of Using Gakushuugoi Model to Enhance Students Japanese Vocabulary Skills
}

\author{
Ihda Rizka Rizalia*, Yuyun Rosliah \\ *Program Studi Pendidikan Bahasa Jepang, Universitas Negeri Semarang, Semarang, Indonesia
}

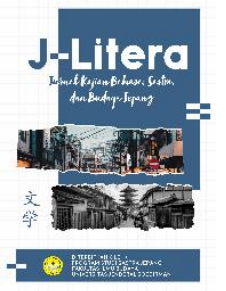

\section{Abstract}

This research aims to determine the effectiveness of gakushuugoi module usage to improve Japanese vocabulary mastery for learners. The method used in this study is an experimental quantitative method, a pre-test and a post-test. The population of sample data in this study is the Japanese elementary level learners (Shokyuu A) of Bimbel AEC Semarang. To determine the effect of Gakushuugoi module usage in the use of Japanese vocabulary, the data analysis was carried out before and after the treatment. From the results of data analysis, it is known that the t count is 7.78 and the $\mathrm{df}$ is 9 . It happens since the value of $\mathrm{t}$ table for $\mathrm{df} 9$ is 2.26 at a significant level of $5 \% \mathrm{t}$ table and 3.25 at a significant level of $1 \% t$ table. Thus, the value of the $t$ count is greater than the $t$ table. This shows that there are significant differences between the variables X (post-test) and variable Y (pre-test). Based on the analysis, it can be concluded that the use of effective gakushuugoi module can improve the mastery of Japanese vocabulary.
\end{abstract}

Keywords:

Effectiveness; Gakushuugoi

Module Usage; Vocabulary

Article Info:

First received:

30 September 2019

Available online:

30 November 2019

\section{INTRODUCTION}

One of the learning centers that conduct a Japanese language learning courses in the Semarang city is Bimbel Akhil Education Center (AEC) Semarang. Based on a preliminary study conducted by the writer through an observation in March 2018, for learning Japanese elementary level A (Shokyuu A) in the AEC Bimbel Semarang, it is known that the vocabulary mastery the learners is still lacking. The concern is that vocabulary has important role in language. Without mastery of vocabulary, the purpose of our conversation will not be conveyed clearly. Learners tend to have difficulty memorizing and mastering vocabulary after being taught. One of the reasons is because the material handbook used in the learning process does not contain vocabulary material in each chapter. That is why students have difficulty memorizing and mastering Japanese vocabulary.

The vocabulary difficulties experienced by Japanese elementary level A (Shokyuu A) in the AEC Bimbel Semarang inspired the writer to make a learning media in the form of a module. According to Nasution (1982: 204) in the book of "Various Approaches in the Learning and Teaching Process", teaching module include the most recent methods which combine the benefits of various other individual teachings such as specific instructional objective, learning at student's own pace, and feedback.

The module in this study is entitled Gakushuugoi which means vocabulary learning. Gakushuugoi module is the title of a Japanese language module that contains a collection of elementary level A vocabulary (Shokyuu A). This study aims to determine the effectiveness of using the module to improve the vocabulary mastery of the elementary level learners (Shokyuu A) of Bimbel AEC Semarang.

This research is a quantitative study with an experimental approach. The population of this research is Japanese language learners of Bimbel AEC Semarang. The sample of this research is the elementary level Japanese learners (Shokyuu A) of Bimbel AEC Semarang. The amount is 10 people. The results of the study were obtained from the pretest and post-test results. 
Willy Kusuma (2017) in a study entitled The Effectiveness of The Use of Japanese Letters Card Learning Media in The Japanese Language Learning upon The Japanese Vocabulary Mastery of Class X Students of SMA Negeri 4 Magelang explain that the focus of the study is the use of Japanese letters card learning media with the aim to find out the effectiveness of the use of Japanese letters card learning media in the Japanese lessons, especially on the mastery of Japanese language vocabulary of grade $X$ students of SMA Negeri 4 Magelang. The method used in this research is the experimental method with the experimental class model and the control class. The analysis technique used is the t-test statistical analysis. From the results of the study it is noted that the use of Japanese letters card learning media is more effective than conventional learning in term of the media usage. The above research used Japanese letter card media to improve vocabulary mastery, whereas in this study, researchers used the module as a medium to improve vocabulary.

From previous studies, it can be concluded that no one has ever researched the use of module to improve the Japanese vocabulary so that this research can be done.

\section{METHOD}

In this study, the writer uses quantitative approach because it is a study in which data in the form of numbers are analyzed/processed using statistical methods (Sugiyono, 2016: 13). The method used in this study is the quasi experiment method. By that, in this experiment, the experimental class and the control class are the same class. To find out the success of the treatment in this study, the initial ability was compared to the final ability after being given a treatment by conducting an initial vocabulary test (pre test) and a final vocabulary test (post test).

\section{RESULT AND DISCUSSION}

From the results of the study, it is obtained the value of the initial test (pre-test) and the final test (post-test). These values can be seen in the table below:

Table 1. Pre-Test \& Post-Test Result

\begin{tabular}{llll} 
NO & $\begin{array}{l}\text { NAME } \\
\text { CODE }\end{array}$ & $\begin{array}{l}\text { PRE-TEST } \\
\text { SCORE }\end{array}$ & $\begin{array}{l}\text { POST-TEST } \\
\text { SCORE }\end{array}$ \\
\hline 1 & OSR & 85 & 95 \\
2 & EFD & 83 & 83 \\
3 & DED & 80 & 100 \\
4 & MDW & 78 & 100 \\
5 & WYP & 68 & 95 \\
6 & FGN & 63 & 70 \\
7 & RDP & 58 & 95 \\
8 & RZI & 58 & 88 \\
9 & DPP & 50 & 80 \\
10 & FRI & 30 & 85 \\
\hline & TOTAL & $\mathbf{6 5 3}$ & $\mathbf{8 9 1}$ \\
\hline
\end{tabular}

Furthermore, to determine the effectiveness of the use of the Japanese vocabulary module Gakushuugoi in improving the ability to remember Japanese vocabulary, it is calculated using the $t$ test formula, namely:

$t=\frac{M x-M y}{\operatorname{SEM} x y}$

$t \quad$ : the coefficient questioned

$M x \quad$ : the mean of post-test score

My : the mean of pre-test score

SEMxy : the standard error of the difference between mean $x$ and mean $y$

The following is the preparation table to find the t count:

Table 2. t-Table

\begin{tabular}{ccccccc}
\hline No. & $\mathbf{X}$ & $\mathbf{Y}$ & $\mathbf{x}$ & $\mathbf{y}$ & $\mathbf{x}^{2}$ & $\mathbf{y}^{\mathbf{2}}$ \\
\hline 1 & 95 & 85 & 5,9 & 19,7 & 34,81 & 388,09 \\
2 & 83 & 83 & -6.1 & 17,7 & 37,21 & 313,29 \\
& & & & & & \\
3 & 100 & 80 & 10,9 & 14,7 & 118,81 & 216,09
\end{tabular}




\begin{tabular}{ccccccl}
4 & 100 & 78 & 10,9 & 12,7 & 118,81 & 161,29 \\
5 & 95 & 68 & 5,9 & 2,7 & 34,81 & 7,29 \\
6 & 70 & 63 & - & $-2,3$ & 364,81 & 5,29 \\
& & & 19.1 & & & \\
7 & 95 & 58 & 5,9 & $-7,3$ & 34,81 & 53,29 \\
8 & 88 & 58 & $-1,1$ & $-7,3$ & 1,21 & 53,29 \\
9 & 80 & 50 & $-9,1$ & $-15,3$ & 82,81 & 234,09 \\
10 & 85 & 30 & $-4,1$ & $-35,3$ & 16,81 & 1,246 \\
\hline$\Sigma$ & 891 & 653 & 0.00 & 0.00 & 844,9 & 1,433 \\
$M$ & 89,1 & 65,3 & & & & \\
\hline
\end{tabular}

Before finding the $\mathrm{t}_{\text {count }}$, the values of the mean, standard deviation, standard error, and standard error of the difference must be found.

The formula to find the mean of both variables is as follow:

$$
\begin{aligned}
\text { Mx } & =\frac{\sum \mathbf{x}}{n} \\
& =\frac{891}{10} \\
& =89,1 \\
M y & =\frac{\sum y}{n} \\
& =\frac{653}{10} \\
& =65,3
\end{aligned}
$$

The formula to find the standard deviation of variable $\mathrm{x}$ and $\mathrm{y}$ is as follow:

$$
\begin{aligned}
\operatorname{Sd} x & =\sqrt{\frac{\sum x^{2}}{n}} \\
& =\sqrt{\frac{844,9}{10}} \\
& =\sqrt{84,49} \\
& =9,191 \\
\operatorname{Sd} y & =\sqrt{\frac{\sum y^{2}}{n}} \\
& =\sqrt{\frac{1,433}{10}}
\end{aligned}
$$

$$
\begin{aligned}
& =\sqrt{0,1433} \\
& =0,378
\end{aligned}
$$

The formula to find the standard error of both variables is as follow:

$$
\begin{aligned}
\text { SEM } x & =\frac{\operatorname{Sd} x}{\sqrt{n-1}} \\
= & \frac{9,191}{\sqrt{10-1}} \\
= & \frac{9,191}{\sqrt{9}} \\
& =\frac{9,191}{3} \\
& =3,063 \\
\text { SEMy } & =\frac{\operatorname{Sd} y}{\sqrt{n-1}} \\
= & \frac{0,378}{\sqrt{10-1}} \\
= & \frac{0,378}{\sqrt{9}} \\
= & \frac{0,378}{3} \\
= & 0,126
\end{aligned}
$$

The formula to find the standard error of the difference is as follow:

$$
\begin{aligned}
\text { SEM } x y & =\sqrt{\operatorname{SEM} x^{2}+\text { SEM } y^{2}} \\
& =\sqrt{3,063^{2}+0,126^{2}} \\
& =\sqrt{9,381+0,015} \\
& =\sqrt{9,396} \\
& =3,06
\end{aligned}
$$
follow:

The formula to find the $t_{\text {count }}$ is as

$$
\begin{aligned}
& t=\frac{M x-M y}{S E M x y} \\
& t=\frac{89,1-65,3}{3,06} \\
& t=\frac{23,8}{3,06} \\
& t=7,78 \text { (nilai } t \text { hitung) }
\end{aligned}
$$




$$
\begin{aligned}
\mathrm{db} & =n-1 \\
& =10-1 \\
& =9
\end{aligned}
$$

From the calculation using the $t_{\text {test }}$ formula, it is obtained the $t_{\text {count }}=7.78$, while the $\mathrm{t}_{\text {table }}$ for $\mathrm{N}=10$ and the degree of freedom (df) $\mathrm{N}-1=9$ is 2.26 with a significance level of $5 \%$. Because the result of the $t_{\text {count }}$ is greater than the $t_{\text {table, }}$ the working hypothesis which is "The Effectiveness of Using The Gakushuugoi Module to Improve Japanese Vocabulary of Bimbel AEC Learners in Semarang" is accepted. This proves that the Japanese vocabulary Module Gakushuugoi is effective for increasing the mastery of Japanese vocabulary.

\section{CONCLUSIONS}

Based on the results of the study, it can be concluded that the use of the 'Gakushuugoi Module' is effective to improve the ability to remember the Japanese vocabulary of elementary level learners (Shokyuu A) of Bimbel AEC Semarang. This is proved by the results of the respondents' tests. The results shows that the highest post-test score obtained after the treatment was 100 and the lowest score was 70 . The average score of the posttest was 89.1. While on the pre-test results, which were carried out before being given the treatment, the highest score obtained was 85 and the lowest score was 30 . The average value of the pre-test results was 65.3.

From the results of calculations using the T-test formula, it is obtained the $t_{\text {count }}=7.78$. While the value of $\mathrm{t}_{\text {table }}$ for $\mathrm{N}=10$ and degrees of freedom (df) $\mathrm{N}-1=9$ are $2.26(5 \%)$ and 3.25 $(1 \%)$. The $\mathrm{T}$ value is greater than the table value (at $5 \%$ significance level). Because the $t_{\text {count }}$ is greater than the $t_{\text {table }}$ value, the working hypothesis which is "The Effectiveness of Using Gakushuugoi Module to Improve Japanese Vocabulary of Bimbel AEC Learners in Semarang" is accepted.

For teachers, the use of Gakushuugoi Module learning media in vocabulary learning activity can improve vocabulary mastery because it is easy to be memorized by students or learners. Therefore, it is recommended for teachers to also be able to use it as an alternative medium in learning Japanese vocabulary.

For researchers who want to conduct similar research, they can add and classify the vocabulary material as research material into many chapters so that the students' or learner's Japanese vocabulary knowledge becomes richer. Especially on other book materials (other than Minna no Nihongo book) which do not contain vocabulary specifically.

\section{REFERENCES}

Anggriani, Dwi Susan. 2014. Pengertian Efektivitas dan Landasan Teori Efektivitas. (http://literaturbook.blogspot.com/201 4/12/27/pengertian-efektivitas-danlandasan. Diakses 24 Februari 2019

Anwar, Ilham. 2010. Pengembangan Bahan Ajar. Bahan Kuliah Online. Direktori UPI. Bandung. \{Vembriarto, St. 1975. Pengantar Pengajaran Modul. Yogyakarta.\}

Azwar, Saifuddin. 2015. Reliabilitas dan Validitas. Yogyakarta: Pustaka Pelajar

Bahri, Syaiful, dan Aswan Zain. 2006. Strategi Belajar Mengajar. Jakarta: PT Rineka Cipta.

Suryosubroto, B. 1983. Sistem Pengajaran dengan Modul. Jakarta: Bina Aksara.

Cece Wijaya (1992), Upaya Pembaharuan dalam Pendidikan dan Pengajaran, Bandung: Remaja Rosda Karya, B. Suryosubroto. (1983) Sistem Pengajaran dengan Modul, Jakarta: Bina Aksara.

Departemen Pendidikan Nasional (2002), Teknik Belajar dengan Modul, Jakarta: Dirjen Pendidikan Dasar dan Menengah.

Djiwondono, Soenardi. 2008. Tes Bahasa: Pegangan Bagi Pengajar Bahasa. Malang: PT Indeks

Kusuma, Willy. 2017. Efektivitas Penggunaan Media Pembelajaran Kartu Huruf Jepang Pada Pelajaran 
Bahasa Jepang Terhadap Penguasaan Kosakata Bahasa Jepang Siswa Kelas X SMA Negeri 4 Magelang . E-Jurnal Prodi Teknologi Pendidikan Universitas Negeri Yogyakarta, Vol.VI Nomor 7 Tahun 2017. Diunduh dari http://journal.student.uny.ac.id/ojs/ind ex.php/fiptp/article/view/8414/8015

Mudlofir, Ali, dan Evi Fatimatur. 2016. Desain Pembelajaran Inovatif. Jakarta: PT Raja Grafindo Persada.
Sudjianto. 1996. Gramatika Bahasa Jepang Modern. Jakarta: Kesaint Blanc. Sugiyono. 2016. Metode Penelitian Pendidikan. Bandung. Alfabeta,cv

S. Nasution. 2003. Berbagai Pendekatan dalam Proses Belajar \& Mengajar. Jakarta: PT Bumi Aksara.

Suharso dan Ana Retnoningsih. (Eds). 2005. Kamus Besar Bahasa Indonesia.Semarang: Widya Karya.

Sutedi, D. (2011). Penelitian Pendidikan Bahasa Jepang. Bandung: UPI Press. 